\title{
Faktor-Faktor Kesulitan Menulis Imla Mahasiswa PBA IAIN Kudus di Masa Pandemi
}

\author{
Fuad Munajat \\ IAIN Kudus, Indonesia \\ fuadmunajat@iainkudus.ac.id
}

\begin{abstract}
This article describes the causes of students' difficulties in writing Islamic scriptures which have become a classic problem in learning the book. These difficulties, in turn, became even greater when the COVID-19 pandemic hit. This study aims to explore 1) Difficulties faced by students in learning Imla, 2) Imla themes which are perceived as difficult by students, and 3) Student perceptions related to online Imla learning. By using a survey method on students who took the Kitabah course, it was found that 1) the difficulties faced by students in learning Islamic teachings were in the form of online lecture models and material for Islamic teachings which were quite complicated both in theory and practice, 2) the themes perceived as difficult according to students included letters- letters added to words but not spoken, punctuation, and washal fashal, 3) the majority of students stated that they were not happy with online learning with $63.1 \%$.

Keywords: Learning difficulties factor, Imla, pandemic era
\end{abstract}

\begin{abstract}
Abstrak
Artikel ini mendeskripsikan penyebab kesulitan mahasiswa dalam menulis imla yang menjadi masalah klasik dalam pembelajaran kitabah. Kesulitan tersebut pada gilirannya menjadi lebih besar ketika pandemic covid 19 melanda. Penelitian ini memiliki tujuan untuk menelusuri 1) Kesulitan yang dihadapi mahasiswa dalam belajar Imla, 2) Tema-tema Imla yang dipersepsikan sulit oleh mahasiswa, dan 3) Persepsi mahasiswa terkait pembelajaran Imla secara online. Dengan menggunakan metode survey pada mahasiswa yang mengambil mata kuliah Kitabah didapati bahwa 1) kesulitan yang dihadapi mahasiswa dalam pembelajaran Imla berupa model kuliah daring dan materi kaidah imla yang cukup rumit baik teori maupun praktik, 2) tema yang dipersepsi sulit menurut mahasiswa antara lain huruf-huruf yang ditambahkan pada kata tetapi
\end{abstract}


tidak diucapkan, pungtuasi, dan washal fashal, 3) mayoritas mahasiswa menyatakan kurang senang dengan pembelajaran online dengan $63,1 \%$.

Kata Kunci: Faktor kesulitan belajar, Imla, era pandemi

$$
\begin{aligned}
& \text { ملخص } \\
& \text { تسلط هذه المقالة الضيوء على أسباب صعوبة الطلاب في كتابة الإملاء التي تمثل مشكلة كلاسيكية }
\end{aligned}
$$

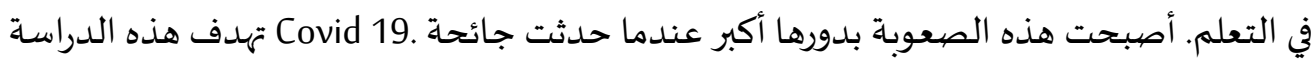

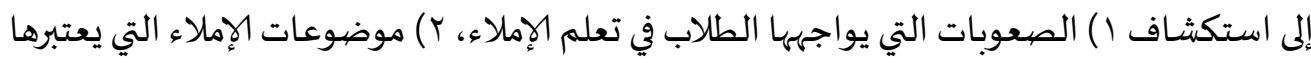

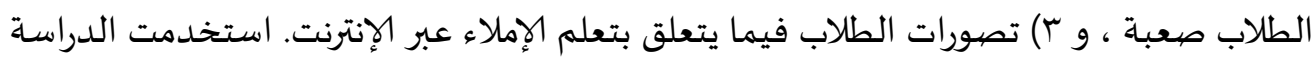

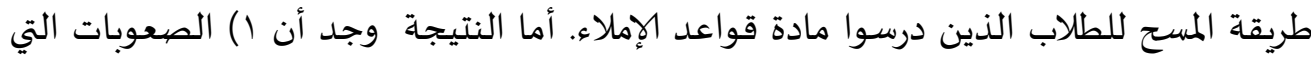

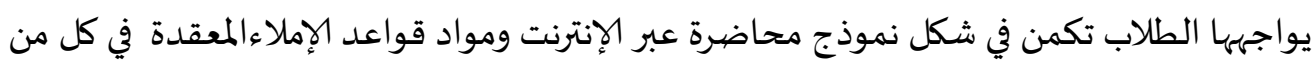

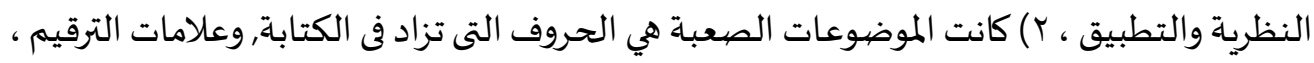

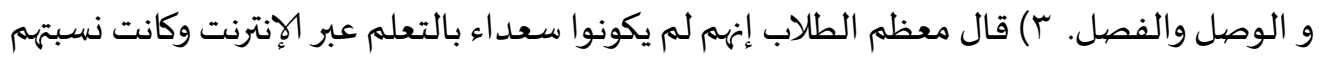

$$
\begin{aligned}
& \text { \% \% } \\
& \text { الكلمات المفتاحية: عوامل صعوبة التعلم، الإملاء، عصر الوباء }
\end{aligned}
$$

\section{A. Pendahuluan}

Menulis merupakan salah satu bentuk keterampilan berbahasa yang menjadi tujuan pembelajaran bahasa Arab. Di luar itu tentu saja ada menyimak, berbicara, dan membaca. Dalam banyak kesempatan, para ahli menyebut keterampilan menulis sebagai keterampilan tertinggi di antara keterampilan-keterampilan yang lain. Hal ini ada benarnya jika yang dimaksud adalah keterampilan menulis gagasan-gagasan atau buah pikiran ke dalam bentuk tulisan baik fiksi maupun non-fiksi.Namun demikian, keterampilan menulis sesungguhnya memiliki beberapa jenis sehingga tidak semuanya dianggap sebagai keterampilan menulis gagasan.

Effendy (2009: 169-170) mengemukakan adanya dua aspek dalam keterampilan menulis yakni pertama kemahiran membentuk huruf dan menguasai ejaan; kedua kemahiran melahirkan pikiran dan perasaan dalam tulisan. Fakhrurrozi \& Mahyudin (2012: 348-349) lebih jauh memetakan keterampilan menulis bahasa Arab ke dalam beberapa kategori yakni pertama kemampuan Imla dan kemampuan mengolah nalar; kedua kemampuan menulis huruf, kata, kalimat, alinea dan wacana; ketiga kemampuan menulis reproduktif, reseptif-produktif dan produktif; dan keempat kemampuan 
menyalin, dikte, mengarang terprogram dan mengarang bebas. Dengan demikian, tampak bahwa ada 2 kutub utama dalam melihat keterampilan menulis yaitu Imla yang didalamnya mencakup apa yang disampaikan Effendy sebagai kemahiran membentuk huruf dan menguasai ejaan atau dalam uraian Fakhrurrozi dan Mahyudin tersebar dalam empat kategorisasi baik Imla, menulis huruf, kata, kalimat, alinea dan wacana, maupun kemampuan mengolah nalar, menulis produktif, mengarang terprogram dan mengarang bebas.

Dalam hal ini, peneliti mengangkat keterampilan Imla yang dalam beberapa referensi berbahasa Arab diwadahi dalam 1 tema besar, alImla.Meskipun secara umum keterampilan mengungkapkan gagasan merupakan tujuan akhir dalam pembelajaran menulis, tidak dapat dipungkiri bahwa keterampilanImla juga tidak dapat diabaikan karena menjadi dasar bagi pengembangan keterampilan yang mengungkapkan gagasan. Lebih jauh Syahhatah (1996: 316-321) menyebutkan beberapa kesulitan Imla bahasa Arab antara lain: bentuk syakl/harakat, kaidah imla, perbedaan bentuk huruf sesuai dengan perbedaan letaknya dalam kata, pemberian titik dalam huruf, penggabungan dan pemisahan huruf, penggunaan vocal pendek, I'rab, perbedaan rasm mushaf dengan rasm umum. Sinyalemen kesulitan imla bahasa Arab sebagaimana disebutkan Syahhatah dihadapi secara nyata oleh penutur Arab (native speaker). Bisa dibayangkan bahwa kondisi yang sama juga dialami pembelajar bahasa Arab non-Arab dan bisa jadi kesulitan tersebut menjadi berlipat ganda. Hal inilah yang mendorong peneliti untuk melaksanakan penelitian "Faktor-faktor Penyebab Kesulitan Imla (Kitabah Aaliyah) Mahasiswa PBA IAIN Kudus" dengan tujuan utama memetakan kesulitan mahasiswa PBA dalam belajar Kitabah Aaliyah apalagi dalam kondisi pandemic Covid 19 saat penelitian ini dilakukan.

Sebagaimana disebutkan di atas bahwa penelitian ini secara garis besar bertujuan untuk memetakan kesulitan belajar Imla dalam bahasa Arab mahasiswa PBA IAIN Kudus.Guna memfokuskan pembahasan pada penelitian 
ini, peneliti merumuskan masalah penelitian ini sebagai berikut: 1) Kesulitan apa yang dihadapi mahasiswa dalam belajar Imla? 2) Tema-tema Imlaapa yang dipersepsikan sulit oleh mahasiswa? 3) Bagaimana persepsi mahasiswa terkait pembelajaran Imla secara online?

Beberapa penelitian dan kajian telah dilakukan dalam rangka mendeskripsikan Faktor-faktor Penyebab Kesulitan Imla (Kitabah Aaliyah) Mahasiswa PBA IAIN Kudusantara lain:

1. Lalu Akmal Hijrat (2020: 1-10) Pembelajaran Khat wa Qowa'idul Imla' Mahasiswa UIN Mataram dan Problematika. Penelitian kualitatif tersebut menyimpulkan tiga hal yakni pertama pentingnya pemilihan metode agar tercapai tujuan yang dikehendaki; kedua, mempelajari khat wa qowaidul imla bukan saja untuk mengoreksi kesalahan mahasiswa tetapi lebih kepada mengantar dan membimbing mahasiswa kepada pengetahuan menulis yang baik dan benar; ketiga, selain ketepatan memilih metode perkuliahan/proses belajar mengajar, penting juga memilih materi teks yang tidak terlalu sulit. Terkait problematika, secara umum disimpulkan bahwa kesalahan dalam penulisan disebabkan tiga hal, factor interal mahasiswa meliputi rendahnya minat atau motivasi belajar, kualitas kecerdasan, penglihatan dan pendengaran yang rendah dan kurang, hilangnya konsentrasi dan perhatian ketika belajar dan kurangnya waktu belajar; factor intern bahasa meliputi panjang dan pendeknya teks yang akan didiktekan kepada mahasiswa seperti teks yang lebih tinggi tingkatannya daripada kemampuan mahasiswa atau banyaknya kata-kata yang rumit dan adanya perbedaan antara huruf, kata atau kalimat yang diucapkan dengan yang ditulis; factor pengajar meliputi pengucapan yang terlalu cepat atau suara yang terlalu rendah, tidak adanya perbedaan pengucapan antara satu huruf dengan huruf yang lain, lemahnya persiapan kebahasaan pengajar dan kurangnya perhatian dan petunjuk pengajar terhadap kesalahan pelajar untuk melakukan perbaikan. 
2. Agus Rohmadi (2008: ii), Problematika Imla dalam Pengajaran Bahasa Arab Pada Siswa Kelas VIII MTsN Wonokromo. Penelitian tersebut bertujuan a) mengetahui proses pembelajaran imla di kelas VIII A MTsN Wonokromo, b) mengetahui problem yang dihadapi siswa kelas VIII A dalam menulis imla, c) mengetahui factor-faktor yang menyebabkan siswa mengalam problem imla, d) mengetahui solusi dalam mengatasi problem imla bagi siswa kelas VIII A MTsN Wonokromo. Metode yang digunakan dalam pengumpulan data adalah observasi, interview, dokumentasi dan tes. Analisis data dilakukan dengan menggunakan metode analisis kualitatif. Hasil penelitian menunjukkan siswa kelas VIII A MTsN Wonokromo menghadapi problem dalam menulis. Factor penyebab kesulitan tersebut pertama, siswa kurang terbiasa dengan menulis imla karena pelajaran imlam kurang menjadi perhatian khusus dari pihak pengajar; kedua factor dari guru yaitu ketika membacakan kata yang diimlakan kurang fasih makhrojnya dan dengan ejaan yang agak cepat; ketiga siswa kurang mengetahui kaidah tulisan Arab; keempat minat siswa yang kurang dalam mengikuti mata pelajaran imla.

3. Selfiana Tafrihah (2014: v), Problematika Pembelajaran Keterampilan Menulis Bahasa Arab pada Kelas V di MI Darul Hikmah Bantarsoka Purwokerto Barat Tahun Pelajaran 2013/2014. Penelitian ini memiliki tujuan untuk mengetahui apa saja problem yang dialami siswa kelas $\mathrm{V}$ dalam belajar keterampilan menulis bahasa Arab, serta upaya apa saja yang dilakukan guru dalam mengatasi problematikan keterampilan menulis bahasa Arab pada kelas V. penelitian dengan jenis kualitatif ini menggunakan teknis pengumpulan data dengan observasi, wawancara dan dokumentasi. Sedangkan teknik analisa datanya menggunakan analisa deskriptif kualitatif. Hasil penelitian tersebut adalah ada 2 segi problematika yakni segi linguistic dan non linguistic. Yang pertama, terkait dengan kesulitan siswa dalam membedakan huruf hijaiyah yang bunyi makhrojnya hamper sama, kesulitan penyambungan huruf, kesulitan 
pemberian harakat. Ini terjadi saat guru mengimlakan kosa kata Arab kepada siswa. Sedangkan saat latihan menyalin di buku tulis, para siswa belum bisa menulis dengan rapid an indah, tulisan mereka masih sulit dibaca. Adapun dari segi non linguistic, ada problem fisiologi yakni terkait dengan keadaan fisik, termasuk kelelahan dan kurang gairah. Selain itu ada juga factor psikologis yang meliputi bakat, kecerdasan dan motivasi.

4. Jumriani (tt: th), Problematika Pembelajaran Maharah al-Kitabah Siswa Kelas XI IPB SMAN 4 Bantaeng. Penelitian tersebut memiliki tujuan untuk a) mendeskripsikan problematika siswa dalam pembelajaran maharah alkitabah siswa kelas XI IPB SMAN 4 Bantaeng, b) Mendeskripsikan problematika guru dalam pembelajaran bahasa Arab siswa kelas XI IPB SMAN 4 Bantaeng, c) Upaya mengatasi problematika pembelajaran menulis bahasa Arab. Penelitian tersebut merupakan penelitian deskriptif dengan instrument penelitian berupa angket, wawancara, dan observasi. Hasil penelitian sebagai berikut: problem yang dialami siswa saat pembelajaran bahasa Arab adalah a) kurangnya minat siswa dalam pembelajaran menulis bahasa Arab, b) kurangnya bimbingan guru, c) kurangnya motivasi dari sekolah. Adapun problem yang dihadapi guru antara lain a) kurangnya pemahaman terhadap siswa, b) kurangnya fasilitas kegiatan pembelajaran.

5. Neli Putri (2012: 173), "Problematika Menulis Bahasa Arab". Artikel yang terdapat pada jurnal Al-Ta'lim, Jilid 1, Nomor 2, Juli 2012 tersebut mengkaji tentang problematika menulis bahasa Arab terutama terkait dengan kesulitan dalam mempraktikan kaidah imlaiyyah mulai dari penulisan kata hingga penulisan kalimat. Dalam uraiannya juga dijelaskan bahwa kesalahan dalam penulisan kata berakibat pada perubahan makna.

Berdasarkan kajian pustaka di atas dapat disebutkan perbedaan antara penelitian terdahulu dengan penelitian yang akan dilaksanakan oleh peneliti. Di antaranya adalah penelitian Lalu Akmal Hijrat (2020) Pembelajaran Khat wa Qowa'idul Imla' Mahasiswa UIN Mataram dan Problematika secara metode 
penelitian, penelitian tersebut berjenis kualitatif sedangkan yang dilakukan peneliti adalah menggabungkan dua metode baik kualitatif maupun kuantitatif. Perbedaan kedua, meski sama-sama dilakukan pada subjek mahasiswa tetapi konteks penelitiannya berbeda, peneliti mengangkat konteks pembelajaran online di tengah pandemic karena berlangsung pada semester gasal TA 2020/2021.Demikian halnya perbedaan dengan penelitian.

Penelitian yang dilakukan Agus Rohmadi (2008), Problematika Imla dalam Pengajaran Bahasa Arab Pada Siswa Kelas VIII MTsN Wonokromo secara subjek sudah tampak perbedaannya. Sementara Selfiana Tafrihah (2014), Problematika Pembelajaran Keterampilan Menulis Bahasa Arab pada Kelas V di MI Darul Hikmah Bantarsoka Purwokerto Barat Tahun Pelajaran 2013/2014 kurang lebih memiliki perbedaan yang sama dengan Agus Rohmadi, bahkan yang pertama lebih menekankan imla mekanis dalam arti yang sangat mendasar yakni menyalin tulisan bahasa Arab.

Penelitian Jumriah (2019) Problematika Pembelajaran Maharah alKitabah Siswa Kelas XI IPB SMAN 4 Bantaeng juga pada jenjang sekolah menengah.sementara yang dilakukan peneliti focus kepada kesulitan yang dihadapi mahasiswa saat belajar Imla (imla) dalam konteks pembelajaran di tengah pandemic.

Sedangkan penelitian literer Neli Putri (2012) lebih memokuskan pada problematika menulis bahasa Arab berdasarkan referensi yang ia dapatkan. Ia sama sekali tidak melakukan penelitian lapangan yang merupakan titik perbedaan dengan apa yang dilakukan peneliti.

Berdasarkan pada perbedaan-perbedaan di atas, peneliti dapat menyebutkan bahwa perbedaan antara penelitian yang akan dilaksanakan dengan penelitian-penelitian sebelumnya dilihat pada dua tataran. Pertama terkait dengan konteks waktu pelaksanaan di era pandemic yang mengharuskan model kuliah daring. Kedua terkait jenjang pendidikan pada jenjang perguruan tinggi meskipun dalam penelitian Lalu Akmal juga pada 
jenjang pendidikan tinggi tetapi model pembelajaran daring tidak menjadi pertimbangan utama.

Mengenai pembelajaran kitabah, Aziz Fakhrurrozi dan Erta Mahyudin (2012: 347) menyatakan bahwa Kitabah (menulis) merupakan pelukisan lambing-lambang grafis yang menggambarkan suatu bahasa yang dipahami seseorang untuk dibaca orang lain. Dalam terminology lain, Syahhatah (1996: 315) menyebut Kitabah sebagai salah satu sarana komunikasi melalui mana siswa dapat mengungkapkan gagasan, bersikap terhadap gagasan orang lain, menunjukkan pemahaman dan perasaannya, dan mencatat kejadian dan peristiwa yang ingin dicatatnya. Di antara ragam kemahiran menulis adalah kemampuan Imla (maharah aliyah) dan kemampuan mengolah nalar. Yang pertama merujuk pada keterampilan yang berkaitan dengan bentuk baku bahasa tulisan, seperti penulisan tanda baca (pungtuasi), penulisan bentuk huruf, huruf-huruf yang bisa ditulis bersambung, huruf-huruf yang hanya bisa disambung dengan huruf sebelumnya dan tidak bisa disambung dengan huruf setelahnya, penulisan hamzah qatha' dan washal, dan sebagainya (Aziz Fakhrurrozi dan Erta Mahyudin, 2012: 348). Sedangkan kemampuan mengolah nalar (maharah aqliyyah) adalah kemampuan yang terkait dengan penggunaan bahasa, pengungkapan isi, keterampilan gaya bahasa, keterampilan menilai, dan kemampuan mengorganisasi. Dalam redaksi lain adalah terkait dengan menuliskan gagasan, perasaan, dan apa saja yang ada dalam pikiran dan hati manusia. Jika melihat cakupannya, apa yang disebut kemampuan mekanis oleh Azis Fakhrurozzi dan Erta Mahyudin adalah muatan yang selama ini menjadi bahan utama dari Qawa'id al-Imla.Dengan demikian sangat beralasan jika peneliti menyamakan antara Imla dengan qawaid al-imla meskipun dalam referensi berbahasa Arab, kata imla sendiri memiliki makna khusus.Mahmud Ahmad As-Sayyid (1997: 537) menyebut kata Imla merupakan bentuk mashdar dari fi'il /amlaytu/ yang bermakna 'talqin' atau dalam bahasa Indonesia disebut 'dikte'. Namun demikian makna imla yang digunakan saat ini adalan menulis dan menjauhi kesalahan dalam penulisan. 
Dalam penelitian ini, peneliti menyamakan kata Imla dengan imla sehingga dipergunakan secara subtitutif. Syahhatah (1996: 316-322) memetakan problematika system tulisan bahasa Arab, sebagaimana telah dibahas ulama-ulama sebelumnya, dalam banyak aspek di antaranya: syakal, qawa'id al-imla, perbedaan bentuk huruf sesuai posisinya dalam kalimat, pemberian titik pada huruf (I'jam), menyambung dan memisah huruf, penggunaan vocal pendek, serta perbedaan tulisan mushaf Al-Qur'an dengan tulisan pada non- Al-Qur'an.

\section{Syakal}

Yang dimaksud dengan syakal adalah pemberian harakat pendek pada huruf baik berupa dhammah, fathah, maupun kasroh.Syakal merupakan sumber pertama dari sumber kesulitan. Kata yang terdiri dari 'ain, lam, dan mim (علم) dapat membingungkan orang yang membacanya karena bisa jadi dibaca 'alima', 'allama', 'ulima', 'ilmun', dan 'alamun'

\section{Kaidah Imla}

Di antara kesulitan kaidah imla sebagai berikut:

a. Perbedaan antara bentuk huruf dengan bunyinya, ini terkait dengan adanya huruf yang ditulis tetapi tidak dibaca dan sebaliknya

b. Keterkaitan kaidah imla dengan nahwu dan sharf sebagaimana contoh kata (علم) di atas.

c. Rumitnya kaidah imla dan banyaknya pengecualian

d. Perbedaan pada kaidah imla, seperti perbedaan ahli Mesir dengan Saudi

e. Perbedaan bentuk huruf sesuai posisinya dalam kalimat

f. Pemberian titik (I'jam)

g. Menyambung huruf dan memisahkannya

h. Penggunaan vocal-vokal pendek

i. I'rab

j. Perbedaan penulisan mushaf dengan tulisan pada umumnya. 
Di antara tujuan pembelajaran imla adalah sebagai berikut (Mahmud Ahmad As-Sayyid: 1997: 538-539):

1. Melatih siswa menulis kata-kata yang benar dan menempelkan citra bentuk kata-kata tersebut dalam benak mereka sehingga mudah menulisnya beranjak dari ingatan

2. Membiasakan ketelitian, keteraturan, urutan, dan kuatnya perhatian

3. Melatih indera keimlaan seperti penglihatan, pendengaran, tangan, dan telinga dalam memahami dan menguasai bahan yang didiktekan

4. Memperluas pengalaman dan perbendaharaan bahasa mereka dengan jalan membekali struktur, bentuk sastrawi, informasi kebudayaan yang berguna dalam pengungkapan tulisan, membaca, sastra, dan kritik sastra.

5. Melatih menuliskan apa yang disimak dalam kecepatan, kejelasan, validitas, dan pemahaman

6. Melatih mendengarkan dan menyimak yang baik.

Hassan Syahhatah (1996: 329-331) menyebut beberapa penyebab terjadinya kesalahan dalam imla terpulang pada beberapa factor antara lain:

1. Faktor-faktor terkait administrasi dan system pembelajaran. Di antaranya adalah: beban guru yang berlebih, meningkatnya intensitas kelas, minimnya jumlah guru, tidak ada motivasi pendorong bagi guru yang mumpuni.

2. Factor-faktor terkait guru. Guru pada jenjang dasar lemah dalam kesiapan bahasanya; guru yang mengajar banyak mata pelajaran cenderung tidak memperhatikan kesalahan tulis siswa

3. Factor-faktor terkait bahasa yang ditulis (bahasa Arab). Hal ini sebagaimana telah dijelaskan pada bagian B (problematika pembelajaran menulis).

4. Factor-faktor terkait siswa. Ini terkait dengan rasa bingung, takut, ketiadaan membedakan antara bunyi-bunyi yang berdekatan, 
ketidakpercayaan terhadap apa yang ditulis, keletihan, lemahnya indra, penurunan tingkat kecerdasan, minimnya perhatian mata, ketidakmampuan mengingat, serta kekurangan lainnya.

5. Factor- factor terkait metode pembelajaran. Misalnya terkait dengan persepsi bahwasanya belajar imla didasarkan atas metode ikhtibariyyah (metode dengan tujuan mengetes) atau asumsi yang mengatakan bahwa kesalahan dalam imla cukup diselesaikan dengan pembetulan di buku tugas, dan sebagainya.

Dari paparan di atas tampak bahwa kesalahan dalam penulisan mekanis tidak berdiri tunggal kesalahan siswa.Padanya terdapat fakta bahwa seluruh komponen pembelajaran terlibat dan memang harus terlibat dalam rangka memperbaiki kualitas tulisan mekanis siswa.

Penelitian ini termasuk dalam kategori penelitian survey dan bersifat deskriptif yang artinya bertujuan untuk menggambarkan keadaan atau fenomena yang terjadi.Penelitian ini dilakukan terhadap mahasiswa semester III yang sedang mengambil mata kuliah Kitabah Qawaid al-Imla wa al-Khath dengan jumlah keseluruhan sebanyak 108 mahasiswa dengan semua dimasukkan sebagai sampel.Data tentang Faktor-faktor Penyebab Kesulitan Imla (Kitabah Aaliyah) Mahasiswa PBA IAIN Kudus dikumpulkan secara online melalui google form. Berdasarkan rekapan data dari google form, diketahui jumlah responden yang mengisi google form sebanyak 76 mahasiswa.Survey dilaksanakan pada 28 - 29 Desember 2020. Pengumpulan data menggunakan kuisioner tertutup, dengan beberapa item semi terbuka, dan jawaban essay. Data yang sudah dikumpulkan kemudian dianalisis menggunakan analisis kuantitatif deskriptif teknik persentase langsung dari google form. Sedangkan jawaban essay dianalisis secara kualitatif dengan model Miles dan Huberman.

\section{B. Pembahasan}

1. Pembelajaran Kitabah 
Aziz Fakhrurrozi dan Erta Mahyudin (Fakhrurrozi \& Mahyudin, 2012) menyatakan bahwa Kitabah (menulis) merupakan pelukisan lambing-lambang grafis yang menggambarkan suatu bahasa yang dipahami seseorang untuk dibaca orang lain. Dalam terminology lain, Syahhatah (Syahatah,1996) menyebut Kitabah sebagai salah satu sarana komunikasi melalui mana siswa dapat mengungkapkan gagasan, bersikap terhadap gagasan orang lain, menunjukkan pemahaman dan perasaannya, dan mencatat kejadian dan peristiwa yang ingin dicatatnya. Di antara ragam kemahiran menulis adalah kemampuan Imla (maharah aliyah) dan kemampuan mengolah nalar. Yang pertama merujuk pada keterampilan yang berkaitan dengan bentuk baku bahasa tulisan, seperti penulisan tanda baca (pungtuasi), penulisan bentuk huruf, huruf-huruf yang bisa ditulis bersambung, huruf-huruf yang hanya bisa disambung dengan huruf sebelumnya dan tidak bisa disambung dengan huruf setelahnya, penulisan hamzah qatha' dan washal, dan sebagainya (Fakhrurrozi \& Mahyudin, 2012). Sedangkan kemampuan mengolah nalar (maharah aqliyyah) adalah kemampuan yang terkait dengan penggunaan bahasa, pengungkapan isi, keterampilan gaya bahasa, keterampilan menilai, dan kemampuan mengorganisasi (Fakhrurrozi \& Mahyudin, 2012). Dalam redaksi lain adalah terkait dengan menuliskan gagasan, perasaan, dan apa saja yang ada dalam pikiran dan hati manusia. Jika melihat cakupannya, apa yang disebut kemampuan mekanis oleh Azis Fakhrurozzi dan Erta Mahyudin adalah muatan yang selama ini menjadi bahan utama dari Qawa'id al-Imla. Dengan demikian sangat beralasan jika peneliti menyamakan antara Imla dengan qawaid al-imla meskipun dalam referensi berbahasa Arab, kata imla sendiri memiliki makna khusus. Mahmud Ahmad As-Sayyid menyebut kata Imla merupakan bentuk mashdar dari fi'il /amlaytu/ yang bermakna 'talqin' atau dalam bahasa Indonesia disebut 'dikte'. Namun demikian makna imla yang digunakan saat ini adalan menulis dan menjauhi kesalahan dalam penulisan (As-Sayyid, 1997).

Dalam penelitian ini, peneliti menyamakan kata Imla dengan imla sehingga dipergunakan secara subtitutif.

a. Problematika Pembelajaran Menulis Bahasa Arab 
Syahhatah (Syahhatah, 1996) memetakan problematika system tulisan bahasa Arab, sebagaimana telah dibahas ulama-ulama sebelumnya, dalam banyak aspek di antaranya: syakal, qawa'id al-imla, perbedaan bentuk huruf sesuai posisinya dalam kalimat, pemberian titik pada huruf (I'jam), menyambung dan memisah huruf, penggunaan vocal pendek, serta perbedaan tulisan mushaf Al-Qur'an dengan tulisan pada non- Al-Qur'an.

1) Syakal

Yang dimaksud dengan syakal adalah pemberian harakat pendek pada huruf baik berupa dhammah, fathah, maupun kasroh. Syakal merupakan sumber pertama dari sumber kesulitan. Kata yang terdiri dari 'ain, lam, dan mim (علم) dapat membingungkan orang yang membacanya karena bisa jadi dibaca 'alima', 'allama', 'ulima', 'ilmun', dan 'alamun'

2) Kaidah imla

Di antara kesulitan kaidah imla sebagai berikut:

(a) Perbedaan antara bentuk huruf dengan bunyinya, ini terkait dengan adanya huruf yang ditulis tetapi tidak dibaca dan sebaliknya

(b) Keterkaitan kaidah imla dengan nahwu dan sharf sebagaimana contoh kata (علم) di atas.

(c) Rumitnya kaidah imla dan banyaknya pengecualian

(d) Perbedaan pada kaidah imla, seperti perbedaan ahli Mesir dengan Saudi

(e) Perbedaan bentuk huruf sesuai posisinya dalam kalimat

(f) Pemberian titik (I'jam)

(g) Menyambung huruf dan memisahkannya

(h) Penggunaan vocal-vokal pendek

(i) I'rab

(j) Perbedaan penulisan mushaf dengan tulisan pada umumnya.

b. Tujuan Pembelajaran Imla

Di antara tujuan pembelajaran imla adalah sebagai berikut (AsSayyid, 1997): 
1) Melatih siswa menulis kata-kata yang benar dan menempelkan citra bentuk kata-kata tersebut dalam benak mereka sehingga mudah menulisnya beranjak dari ingatan

2) Membiasakan ketelitian, keteraturan, urutan, dan kuatnya perhatian

3) Melatih indera keimlaan seperti penglihatan, pendengaran, tangan, dan telinga dalam memahami dan menguasai bahan yang didiktekan

4) Memperluas pengalaman dan perbendaharaan bahasa mereka dengan jalan membekali struktur, bentuk sastrawi, informasi kebudayaan yang berguna dalam pengungkapan tulisan, membaca, sastra, dan kritik sastra.

5) Melatih menuliskan apa yang disimak dalam kecepatan, kejelasan, validitas, dan pemahaman

6) Melatih mendengarkan dan menyimak yang baik.

c. Sebab-Sebab Kesalahan Imla

Beberapa penyebab terjadinya kesalahan dalam imla terpulang pada beberapa factor antara lain (Syahhatah, 1996):

1) Faktor-faktor terkait administrasi dan system pembelajaran. Di antaranya adalah: beban guru yang berlebih, meningkatnya intensitas kelas, minimnya jumlah guru, tidak ada motivasi pendorong bagi guru yang mumpuni.

2) Factor-faktor terkait guru. Guru pada jenjang dasar lemah dalam kesiapan bahasanya; guru yang mengajar banyak mata pelajaran cenderung tidak memperhatikan kesalahan tulis siswa

3) Factor-faktor terkait bahasa yang ditulis (bahasa Arab). Hal ini sebagaimana telah dijelaskan pada bagian B (problematika pembelajaran menulis).

4) Factor-faktor terkait siswa. Ini terkait dengan rasa bingung, takut, ketiadaan membedakan antara bunyi-bunyi yang berdekatan, ketidakpercayaan terhadap apa yang ditulis, keletihan, lemahnya indra, penurunan tingkat kecerdasan, minimnya perhatian mata, ketidakmampuan mengingat, serta kekurangan lainnya. 
5) Factor- factor terkait metode pembelajaran. Misalnya terkait dengan persepsi bahwasanya belajar imla didasarkan atas metode ikhtibariyyah (metode dengan tujuan mengetes) atau asumsi yang mengatakan bahwa kesalahan dalam imla cukup diselesaikan dengan pembetulan di buku tugas, dan sebagainya.

Dari paparan di atas tampak bahwa kesalahan dalam penulisan mekanis tidak berdiri tunggal kesalahan siswa. Padanya terdapat fakta bahwa seluruh komponen pembelajaran terlibat dan memang harus terlibat dalam rangka memperbaiki kualitas tulisan mekanis siswa.

\section{Metode Penelitian}

a. Jenis dan pendekatan Penelitian

Penelitian ini termasuk dalam kategori penelitian survey dan bersifat deskriptif yang artinya bertujuan untuk menggambarkan keadaan atau fenomena yang terjadi.

b. Populasi dan sampel

Penelitian ini dilakukan terhadap mahasiswa semester III yang sedang mengambil mata kuliah Kitabah Qawaid al-Imla wa al-Khath dengan jumlah keseluruhan sebanyak 108 mahasiswa dengan semua dimasukkan sebagai sampel.

c. Instrumen Penelitian

Data tentang Faktor-faktor Penyebab Kesulitan Imla (Kitabah Aaliyah) Mahasiswa PBA IAIN Kudus dikumpulkan secara online melalui google form. Berdasarkan rekapan data dari google form, diketahui jumlah responden yang mengisi google form sebanyak 76 mahasiswa. Survey dilaksanakan pada 28 - 29 Desember 2020. Pengumpulan data menggunakan kuisioner tertutup, dengan beberapa item semi terbuka, dan jawaban essay.

d. Teknik Analisis Data

Data yang sudah dikumpulkan kemudian dianalisis menggunakan analisis kuantitatif deskriptif teknik persentase langsung dari google form. 
Sedangkan jawaban essay dianalisis secara kualitatif dengan model Miles dan Huberman.

3. Kesulitan Belajar Imla'

a. Kesulitan yang dihadapi mahasiswa dalam belajar Imla

Data tentang kesulitan mahasiswa berasal dari kuesioner terbuka berupa isiian essai yang dapat diisi berdasarkan kondisi masing-masing mahasiswa sebagai berikut:

\begin{tabular}{lll}
\hline No & \multicolumn{1}{c}{ Kesulitan } & Jumlah \\
\hline 1 & Model pembelajaran daring/online & 22 \\
\hline 2 & Sulitnya kaidah imla secara keseluruhan & 19 \\
\hline 3 & Sulitnya penerapan kaidah imla & 17 \\
\hline 4 & Sulit memahami materi yang dipresentasikan oleh & 11 \\
& teman-teman sekelas & \\
\hline 5 & Bahan ajar berbahasa Arab & 7 \\
\hline & Berdasarkan data google form yang peneliti share pada 28-29
\end{tabular}

Desember 2020 di grup WA mata kuliah masing-masing kelas (ada 3 kelas yakni A3BAR, B3BAR, dan C3BAR) diperoleh beberapa data mengenai kesulitan pembelajaran Kitabah Mekanis (Mata kuliah Kitabah Qawaid al-Imla wa al-Khat) yang terangkum pada 3 pertanyaan sebagai berikut: 1) Kesulitan apa yang dihadapi mahasiswa dalam belajar Imla?2)Tema-tema Imla apa yang dipersepsikan sulit oleh mahasiswa?3)Bagaimana persepsi mahasiswa terkait pembelajaran Imla secara online?

Terkait kesulitan apa yang dihadapi mahasiswa dalam belajarImla, datanya diperoleh melalui kuisioner dengan model pertanyaaan essai sehingga masing-masing mahasiswa dapat mengungkapkan apa yang betul-betul dialaminya. Berdasarkan jawaban yang diberikan setidaknya ada beberapa klaster yang merupakan himpunan beberapa kesulitan sebagai berikut: 
1) Sebanyak 22 mahasiswa menitikberatkan kesulitan yang dihadapi dalam pembelajaran Imla (Kitabah Qawaid al-Imla wa al-Khat) disebabkan model pembelajaran daring/online yang masih ditemukan ketidakkuatan sinyal, kekurangan fitur voice note WA atau kalau pun menggunakan google meet sering terkendala sinyal. Ini adalah peringkat pertama yang dikeluhkan mahasiswa dalam perkuliahan Kitabah Qawaid al-Imla wa alKhat.

2) Sebanyak 19 mahasiswa menitikberatkan kesulitan kaidah imla secara keseluruhan dan kaidah-kaidah tertentu seperti hamzah washal, huruf yang harus dibuang dan seterusnya. Ini menandakan dari sisi internal materi kaidah imla memang cukup kompleks.

3) Sebanyak 17 mahasiswa menitikberatkan kesulitan pada aspek penerapan kaidah imla, mereka pada dasarnya dapat memahami materi atau bahan ajar tetapi dalam penerapannya masih kurang optimal.

4) Di urutan keempat ada 11 mahasiswa yang merasa kurang/sulit memahami atau kurang menguasai materi yang disajikan terutama materi yang dipresentasikan oleh teman-teman sekelas

5) Sebanyak 7 mahasiswa menitikberatkan kesulitan pada bahan ajar/materi/ materi tertentu yang ditulis dalam bahasa Arab. Hal ini juga masih terkait dengan poin 4 yang menjadi akibat dari poin kelima ini.

Dengan demikian dapat disimpulkan bahwasanya model pembelajaran online/ daring yang selama ini dilaksanakan saat pandemic perlu dikaji ulang. Sebenarnya mahasiswa tersebut telah mendapatkan bantuan kuota yang cukup besar dari kampus akan tetapi persoalan dan problematika tidak hanya kuota tetapi juga sinyal yang tidak stabil karena terkait coverage masing-masing provider 
yang berbeda-beda di tiap wilayah. Di samping perkuliahan online yang masih dikeluhkan adalah kaidah-kaidah imla itu sendiri yang terdiri dari banyak kaidah dan terkait dengan disiplin ilmu lain seperti Nahwu dan Sharf. Kesulitan ini merupakan kesulitan internal bahasa Arab, belum lagi jika dikaitkan dengan adanya perbedaan antara kaidah imla secara umum dengan kaidah rasm al-Qur'an yang menggandakan kesulitan tersebut.Yang tidak kalah penting adalah kesulitan dalam penerapan kaidah imla dalam bentuk penulisan kalimat atau paragraph.Ini tentu terkait dengan pemahaman terhadap kaidah dan sejauh mana pemahaman tersebut diaplikasikan saat menulis.Bisa jadi menulis yang dimaksud di sini terbatas pada penulisan kalimat pendek dan tidak sampai pada menulis paragraph.

b. Tema-tema Imla yang dipersepsikan sulit oleh mahasiswa

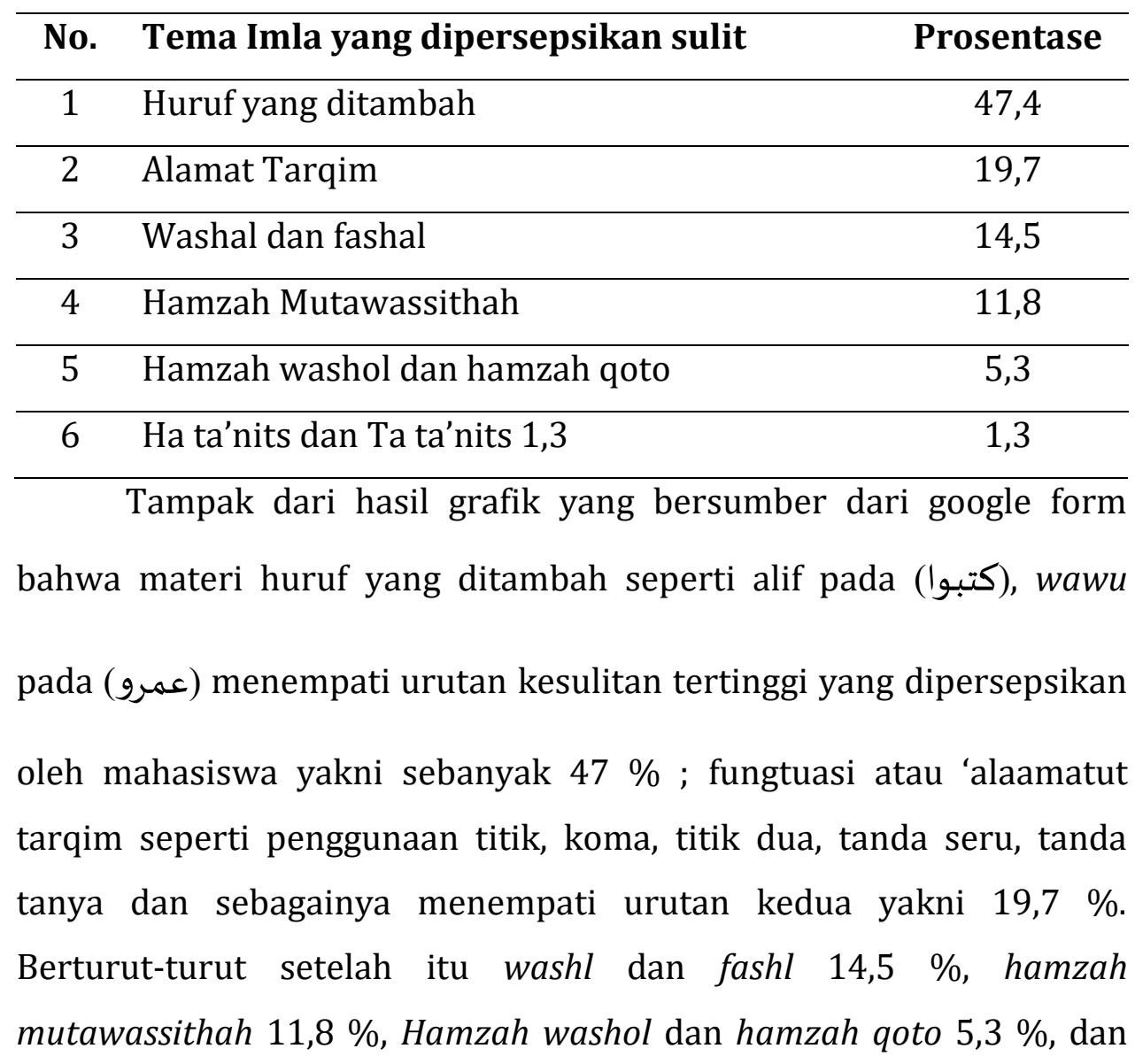


Ha ta'nits dan Ta ta'nits 1,3 \%. Hal ini menunjukkan bahwa materi yang secara tertulis tidak dilafalkan tetapi ditulis menjadi hambatan terbesar mahasiswa sedangkan tema Ta ta'nis dan Ha ta'nis bukan merupakan hambatan karena sejak di bangku madrasah Ibtidaiyyah mereka sudah sangat familiar dengan bentuk nyata $t a^{\prime} t a^{\prime} n i s$ baik maftuhah maupun marbuthah. Adapun terkait pungtuasi atau tanda baca, meski secara umum semua bahasa menggunakannya secara seragam, tetapi untuk kasus bahasa Arab bisa dikatakan contoh yang ada dalam buku referensi menunjukkan ketidaksamaan penggunaanya sehingga angka kesulitan menempati posisi kedua dengan 19,7 \% dan ini cukup mengagetkan. Analisa lain dapat disampaikan di sini bahwa kebiasaan mahasiswa dalam membaca kitab turas dengan tanpa pungtuasi bisa jadi menjadi penyebab lain dari kesulitan tersebut.

c. Persepsi mahasiswa terkait pembelajaran Imla secara online

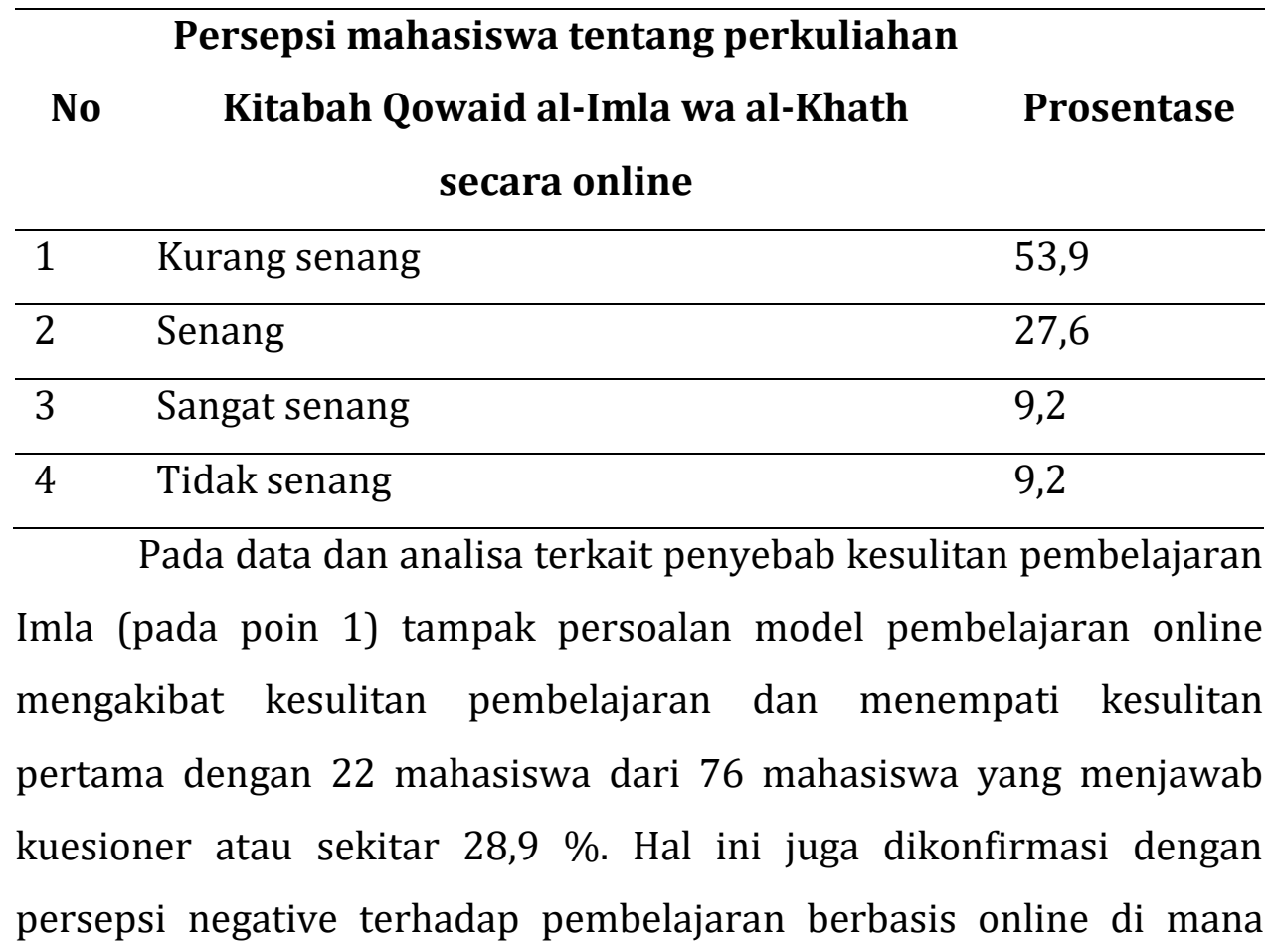


jumlah mahasiswa yang menjawab kurang senang 53,9 \%. Grade ini merupakan grade ketiga dari urutan positive ke negative (sangat senang - senang - kurang senang - tidak senang). Tentu saja buruknya sinyal, hambatan suara, gambar, dan sebagainya tidak akan mereka alami jika mereka melaksanakan kuliah model luring atau offline. Di peringkat kedua dengan kategori "senang" 27,6 \%, cukup memberikan arti positif. Biasanya yang mengisi ini adalah mereka yang secara sinyal tidak mengalami hambatan tersebut dan mereka bertempat tinggal di wilayah perkotaan. Kategori ketiga dan keempat "sangat senang" dan "tidak senang" berbagi prosentase dengan 9,2\%. Secara prosentasi hasil yang berkonotasi negative mendominasi dengan $63,1 \%$.

Hasil ini, sebagaimana yang sudah dinyatakan di muka, menegaskan bahwa model pembelajaran daring memang perlu dikaji ulang karena berdampak pada kurangnya pemahaman dan penguasaan mahasiswa terhadap materi yang disampaikan dan pada gilirannya membuat mereka kesulitan dalam mempraktikan Imla.

\section{SIMPULAN}

Berdasarkan jawaban yang diberikan setidaknya ada beberapa klaster yang merupakan himpunan beberapa kesulitan.Kesulitan yang dihadapi mahasiswa dalam pembelajaran Imla dapat digambarkan dengan 5 klaster utama yakni kesulitan disebabkan model pembelajaran daring/online, kesulitan kaidah imla secara keseluruhan, kesulitan pada aspek penerapan, kurang menguasai materi, serta kesulitan pada bahan ajar yang ditulis dalam bahasa Arab. Terkait tema imla yang dipersepsi sulit antara lain huruf yang ditambah, pungtuasi, washl dan fashl, hamzah mutawassithah, hamzah washol dan hamzah qoto, serta $\mathrm{Ha}$ ta'nits dan Ta ta'nits. Sedangkan persepsi mahasiswa terkait pembelajaran Imla secara online, lebih dari separuh mahasiswa menjawab kurang senang. 


\section{DAFTAR PUSTAKA}

Agus Rohmadi, "Problematika Imla dalam Pengajaran Bahasa Arab Pada Siswa Kelas VIII MTsN Wonokromo", Skripsi, 2008

Ahmad Fuad Effendy, Metodologi Pengajaran Bahasa Arab, Malang: Misykat, Cet. 4, 2009

Aziz Fakhrurrozi dan Erta Mahyudin, Pembelajaran Bahasa Arab, Direktorat Jenderal Pendidikan Islam Kementerian Agama, 2012

Fahmi An-Najjar, Qawa'id al-Imla fi 'Asyrati Durusin Sahlah, Ar-Riyadl: Fahrasat Maktabah al-Malik Fahd al-Wathaniyyah, 2008

Hasan Syahhatah, Ta'lim al-Lugah al-'Arabiyyah Bayna an-Nadzariyyah wa atTathbiq, Al-Qahirah: ad-Dar al-Mishriyyah al-Lubnaniyyah, ath-Thab'ah ats-Tsalitsah, 1996

Jumriani, “Problematika Pembelajaran Maharah al-Kitabah Siswa Kelas XI IPB SMAN 4 Bantaeng," http://eprints.unm.ac.id/15146/

Lalu Akmal Hijrat, "Problematika Pembelajaran Khat Wa Qowa'idul Imla' Mahasiswa UIN Mataram." Islamiyah, Jurnal Pendidikan dan Wawasan Studi Islam, Volume 2,2020

Mahmud Ahmad As-Sayyid, Fi Tharaiq Tadris al-Lugah al-'Arabiyyah, Mansyurat Jami'ah Dimasyq, ath-Thab'ah ats-Tsaniyyah, 1997

Neli Putri, “Problematika Menulis Bahasa Arab”. Artikel yang terdapat pada jurnal Al-Ta'lim, Jilid 1, Nomor 2, Juli 2012

Selfiana Tafrihah, "Problematika Pembelajaran Keterampilan Menulis Bahasa Arab pada Kelas V di MI Darul Hikmah Bantarsoka Purwokerto Barat Tahun Pelajaran 2013/2014," Skripsi, 2014

Sugiyono, Metode Penelitian Pendidikan: Pendekatan Kuantitatif, Kualitatif, dan $R \& D$, Bandung: Alfabeta, Cet. Ke-17, 2013 